Integritas 2.2 (Fall 2013), pp. 1-18.

doi: $10.6017 /$ integritas.v2i2p1

\title{
Friendship and Contemplation: An Exploration of Two Forces Propelling the Transcendent Hope and Power of the Liberal Arts
}

\begin{abstract}
Marian K. Díaz
The liberal arts do not exist in a vacuum abstracted from teachers and students who with their very lives seek knowledge, love, and wholeness. The transcendent hope and power of the liberal arts come to life precisely within communities of learners. This paper proposes a vision for Catholic higher education driven fundamentally by friendship and contemplation. Beginning with Aristotle's treatment of these themes and moving through the contributions of Augustine and Thomas, this paper explores Christian notions of friendship and contemplation and how their presence within a Catholic university can serve as an occasion of grace for the activation of the transcendent hope and power of the liberal arts.
\end{abstract}

\section{Introduction}

The liberal arts do not exist in a vacuum, abstracted from teachers and students who with their very lives seek knowledge, love, and wholeness. Whatever transcendent hope and power the liberal arts might have to offer comes to life precisely within communities of learners. Multiple communities comprise the modern college or university in a web of relations, sometimes bound by space and location but now increasingly defined by

Marian K. Díaz currently serves as an Assistant Professor of Practical Theology, Institute of Pastoral Studies, Loyola University Chicago. Prior to her husband's appointment as the U.S. Ambassador to the Holy See, she served as the Director of "Companions on a Journey" at the College of Saint Benedict and "Corad: Heart Speaks to Heart" at St. John's University. These initiatives were part of the Programs for Theological Exploration of Vocation, funded by Lilly Endowment, Inc. These grants enabled programming for all university constituencies on the themes of personal and institutional vocation with a special focus on the institution's joint Catholic and Benedictine mission. Marian's theological interests include Scripture and early Church history, discernment of vocation, practical theology, and women in the global church. 
access to a computer network. The context of Catholic higher education also includes persons of all faiths and persons of no faith.

This paper does not seek to explore the multiple understandings of the liberal arts either in the ancient or contemporary world. Instead, for the purpose of this paper, the liberal arts will be considered simply as diverse approaches to learning, including content and methods. "Transcendence" indicates something that has the continual capacity to go beyond itself. "Contemplation" has the basic meaning of "seeing, gazing," but it can also mean "knowing, studying, and theorizing." People engage in contemplation of objects, friends, or God. "Friendship" includes friendship with other persons and with God.

The primary question for this exploration is, What motivates the transcendence of the liberal arts? What provides increasing power and hope to deep and sustained education? This paper proposes that friendship and contemplation share a rootedness in relationship and pursuit of understanding, and so can serve as the fundamental context from which the transcendent hope and power of the liberal arts might flourish for all members of the campus community.

The transcendent power of the liberal arts in Catholic higher education arises from experiences of the graces of friendship and contemplation, in the varied senses of these words. Friendship and contemplation, from Christian perspectives, embody particular expressions of, or ways of living out, the basic origin and goal of all of Christian life, as expressed by Jesus in the Great Commandment.

One of the scribes, when he came forward and heard them disputing and saw how well he had answered them, asked him, "Which is the first of all the commandments?" Jesus replied, “The first is this: 'Hear, O Israel! The Lord our God is Lord alone! You shall love the Lord your God with all your heart, with all your soul, with all your mind, and with all your strength.' The second is this: 'You shall love your neighbor as yourself.' There is no other commandment greater than these." The scribe said to him, "Well said, teacher. You are right in saying, 'He is One and there is no other than he.' And 'to love him with all your heart, with all your understanding, with all your strength, and to love your neighbor as yourself' is worth more than all burnt offerings and sacrifices." And when Jesus saw that (he) answered with understanding, he said to him, "You are not far from the kingdom of God." And no one dared to ask him any more questions.

Friendship and contemplation both involve active love of God, self, and our neighbors. The primary call of Jesus is no less than to love God with our entire being, our entire personhood-mind, heart, soul, and body. The call to Christian discipleship involves growing in our capacity for and living expression of this love each and every day of our lives.

This paper will proceed in three main sections. First, a basic exposition of friendship and contemplation in Aristotle, Augustine, and Aquinas will provide the initial content for 
our conversation by identifying their understandings of friendship and contemplation. Second, the paper will explore the relationship between friendship and contemplation with a focus on some of their characteristics that help prepare the fertile soil for the growth of the transcendence of the liberal arts. Third, the paper will introduce some areas requiring further attention and reflection so that this proposal might have merit and bear fruit on the campuses of Catholic colleges and universities.

\section{Friendship and Contemplation in Aristotle, Augustine, and Aquinas}

\section{Aristotle}

The paper begins with Aristotle for his systematic and thorough treatment of both friendship and contemplation. Aristotle certainly influenced both Christian writers to some extent. Augustine eventually followed neo-Platonic thought more closely, while Aquinas later reintroduced Aristotle to the Christian world.

Aristotle treats friendship and contemplation mainly in the Nicomachean Ethics, the Eudemian Ethics, and the Magna Moralia. ${ }^{2}$ Many writers have noted the apparent contradiction or at least ambiguity in Aristotle concerning how he views the relationship of contemplation, virtue (manifested in friendship), and eudaimonia (the best possible life. $)^{3}$ Aristotle identifies the contemplative life and the political and vulgar lives as three types of lives. ${ }^{4}$ The vulgar life identifies happiness with pleasure, and the political life has virtue as its end. The contemplative life aims toward no other end but itself, and all other characteristics of a supremely happy person are connected to it. The contemplative life reflects the highest form of virtue as it involves the use of reason to contemplate truth more continuously. The pursuit of wisdom provides great pleasure, leisure, and self-sufficiency.

If reason is divine, then, in comparison with man, the life according to it is divine in comparison with human life. But we must not follow those who advise us, being men, to think of human things, and, being mortal, of mortal things, but must, so far as we can, make ourselves immortal, and strain every nerve to live in accordance with the best thing in us; for even if it be small in bulk, much more does it in power and worth surpass everything. ${ }^{5}$

For humanity, life in accordance with reason is most proper, best, and most pleasant. The contemplative life simply is the best form of life.

Aristotle supports this notion with a theological argument. The highest activity of God

2 Aristotle, The Basic Works of Aristotle, ed. Richard McKeon (New York: Random House, 1941).

3 For example, see Amelie Oksenberg Rorty, "The Place of Contemplation in Aristotle's Nicomachean Ethics," Mind: A Quarterly Review of Philosophy 87 (1978), 343-358, and Martha Nussbaum, The Fragility of Goodness: Luck and Ethics in Greek Tragedy and Philosophy (New York: Cambridge University Press, 1986), 354-369.

4 Nicomachean Ethics (NE) 1095b 15-20. Please note that when Aristotle explores the contemplative life and virtue friendships he considers them as elements of life for men and not women. This paper will return to this question in section three.

5 NE 1178a 1-2. 
is contemplation and humans can pursue something like this divine contemplation. ${ }^{6}$ While reason separates us from the animals, Aristotle does not argue for the primacy of reason because it is distinctive to humans; God also contemplates.7 Happiness is coextensive with contemplation. ${ }^{8}$ The gods love the philosopher who grows in reason. ${ }^{9}$ Yet, because of our human nature and lack of self-sufficiency, the contemplative life requires material goods, about the same amount as the political life would. ${ }^{\text {Io }} \mathrm{A}$ contemplative lives with others and desires to exercise virtue. He needs other people and material goods. ${ }^{\text {II }}$

The Eudemian Ethics treats contemplation of God as the final end. All other aspects of life must serve contemplation. ${ }^{22}$ God does not need our contemplation, but God is the reason why people contemplate. Contemplatives cannot be completely self-sufficient. Besides the practical needs of life, contemplatives need friends around them. But how does Aristotle understand friendship?

Aristotle defines three types of friendship by their ends. Friendships may be based on mutual utility, pleasure, or virtue. The virtue friendship, marked by mutual benevolence, is the best because it is most durable and most rare. ${ }^{13}$ This friendship occurs among men who are equal. Friendship constitutes the moral life. "We say that all justice and injustice have a particular bearing on friends; and we think that the same man is both 'good' and a 'friend,' and that friendship is a state connected to character." "I4 Friendship takes on a very high value, a megiston agathon, a greatest good, and aphilia and eremia (friendlessness and solitude) are most terrible. ${ }^{15}$

Aristotle has a deep sense that to be friends means to desire to be together. ${ }^{16}$ In fact, Aristotle frequently states that friends are meant to live together. ${ }^{17}$ Mutuality reflects the desire to be together. One friend loves and values the other friend while being loved and valued by the other friend.

Aristotle sees loving as better than being loved. ${ }^{18}$ Humans praise other humans and recognize each other as virtuous for active loving. In the Eudemian Ethics, Aristotle

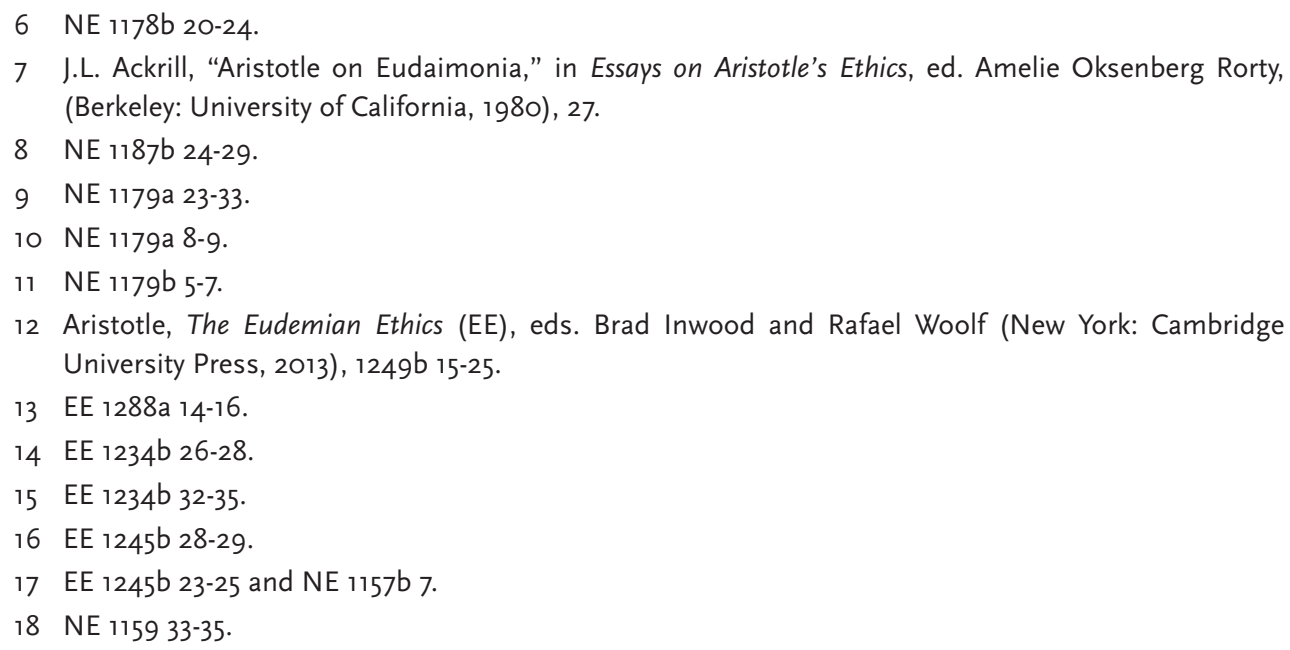


develops why active love exceeds passive love. While animate things can love, an inanimate thing can only be loved. ${ }^{19}$ Aristotle also only associates feeling pleasure with loving and not with being loved. ${ }^{20}$ He raises the question of the self-sufficient person (for example, the contemplative), and whether or not that person would need a friend. He argues that like God, the best person would be self-sufficient and not need friends. The best person, then, would have the fewest friends. Aristotle would agree that God does not need friends, but human social life requires perception and knowing. ${ }^{2 \mathrm{I}}$ Through knowing things (and persons), humans come to know the self. Aristotle then articulates the understanding of friends as anotherself. ${ }^{22}$ Friends share the end. Such friends share daily pleasures such as eating, but they also study together. "It is always better to contemplate (theorein) oneself (through your friend) engaged with a better good." ${ }^{23}$ Their partnership (koinonia) will surely be a sharing in the end (telos).

\section{In sum, friendship and contemplation have much to offer our Catholic colleges and universities by way of encouraging the development of authentic relationships that allow for the seeking of the fullness of human personhood and mutual understanding.}

The Magna Moralia actually states that the self-sufficient man needs friendship in order to grow in self-knowledge. ${ }^{24}$ Direct contemplation (theasasthai) of the self is impossible. ${ }^{25}$ One contemplates the friend, the second self, and so comes to know the self better and to value the self more. Spending time with friends, living with them and sharing activities with them, guides friends in living the virtuous life. The notion of the friend as a second self should not be taken as a mere reduction of friendship to self-love.

Aristotle's argument, in short, is that in loving and valuing the other person and his life for his own sake one becomes able to love and value oneself, and this he offers in explanation and illumination of the fact that the friend loves and values his friend for his own sake and places a high value on doing so. ${ }^{26}$

\footnotetext{
19 EE 1237a 38-40.

20 EE $1237 a 37$.

21 EE 1244b 24-26.

22 EE 1245a 32-36.

23 EE 1245b 1-3.

24 Magna Moralia (MM) 1213a 24-26.

25 MM 1213a 15-16.

26 John M. Cooper, "Aristotle on Friendship," in Essays on Aristotle's Ethics, ed. Amelie Oksenberg Rorty, (Berkeley: University of California, 1980), 333.
} 
For Aristotle, contemplation and friendship provide the most pleasure, the greatest level of virtue, connection to divinity, and hence, transcendence. People contemplate themselves in and through their friends. Contemplation of truth and study of the world occurs within friendship. The practice of virtue through friendship also increases knowledge and understanding as well as honor. In sum, friendship and contemplation have much to offer our Catholic colleges and universities by way of encouraging the development of authentic relationships that allow for the seeking of the fullness of human personhood and mutual understanding.

\section{Augustine}

Christian concepts of friendship and contemplation root themselves in faith and wisdom. In Confessions, St. Augustine writes extensively about his friendships and the positive and negative impacts that they have had on him as a person, both before and after his conversion. From a contemporary perspective, the reader might presume that particular friendships inhibit Christian love (in the sense of agapic and universal love), but for Augustine (and Aquinas will follow him), particular friendships were precisely the way to practice and grow in Christian love. ${ }^{27}$ Paul Wadell follows Marie Aquinas McNamara in emphasizing four points of friendship for Augustine:

First, the author and giver of friendship is God. Second, friendship must be rooted in God and seek God. Third, Christian friendship is transformed by grace. Fourth, it does not end with the Kingdom, but there reaches its perfection when everyone has perfect friendship with God. ${ }^{28}$

Hence, friendships originate, occur, and come to fulfillment only in conjunction with God's grace, and only as one's friendship with God becomes more intimate. Friendship with God initiates on earth but comes to complete fulfillment only in the city of God, where the perfection of Christian friendships and new life with God and the saints will be realized.

Augustine addresses the contemplative life by way of reflection on the story of Jesus' visit to Mary and Martha from the Gospel of Luke. ${ }^{29}$

As they continued their journey he entered a village where a woman whose name was Martha welcomed him. She had a sister named Mary (who) sat beside the Lord at his feet listening to him speak. Martha, burdened with much serving, came to him and said, "Lord, do you not care that my sister has left me by myself to do the serving? Tell her to help me." The Lord said to her in reply, "Martha, Martha, you are anxious and worried about many things. There is need of only one thing. Mary has chosen the better part and it will not be taken from her." (Lk Io: $38-42 \mathrm{NAB}$ )

27 Paul Wadell, Friendship and the Moral Life (Notre Dame, IN: University of Notre Dame Press, 1989), 101-102.

28 Wadell, 97. See also Marie Aquinas McNamara, O.P., Friendship in Saint Augustine (Friborg: University Press, 1958), 196-197.

29 Augustine, Sermons, Edmund Hill, trans. (Brooklyn, NY: New City Press, 1990), Sermon 54. 
Augustine follows the typical interpretation of this passage as a statement that the contemplative life excels the active life. Augustine, however, also connects the fullness of the contemplative life to life in heaven. So, in a way, the active life is still required for people and for the Church on earth.

\section{Aquinas}

Aquinas addresses the active and contemplative lives in the Summa Theologica Q. I82, articles I-4. He begins by arguing for the primacy of the contemplative over the active life. The contemplative life has more value for reasons that come very close to the list in Aristotle: the contemplative life involves reason, is divine and the most self-sufficient, and can be continuous. Contemplation provides delight and leisure. In addition to these reasons, Aquinas adds that God's light enlightens the contemplative and he, too, points to Mary, in Luke Io:42, saying that she has chosen the better part..$^{\circ}$ The contemplative life involves loving God with the whole self, including the will and the affect..$^{31}$ Aquinas also follows Augustine in emphasizing that God's creation also makes up part of the content of the contemplative life.

The contemplation of the divine effects also belongs to the contemplative life, inasmuch as man is guided thereby to the knowledge of God. Hence Augustine says (De Vera Relig. xxix) that "in the study of creatures we must not exercise an empty and futile curiosity, but should make them the stepping-stone to things unperishable and everlasting." ${ }^{2}$

Finally, Aquinas does not reject the active life, but argues that the active life provides a training ground for the contemplative life. Overall, the perfection of the Christian life rests in charity. "The Christian life consists chiefly in charity whereby the soul is united to God." 33

Aquinas connects charity to love of God and friendship with God. Within this question on the relationship of the virtues, Aquinas addresses whether or not charity can exist without faith and hope. He uses the image of human friendships applied to our friendship with God to answer the question. Charity indicates mutual friendship as a communion of love with God. He continues,

Now this fellowship of man with God, which consists in a certain familiar colloquy with Him, is begun here, in this life, by grace, but will be perfected in the future life, by glory; each of which things we hold by faith and hope. Wherefore just as friendship with a person would be impossible, if one disbelieved in, or despaired of, the possibility of their fellowship or familiar colloquy; so too, friendship with God, which is charity, is impossible without faith, so as to believe

30 Thomas Aquinas, Summa Theologica (ST), Fathers of the English Dominican Province, trans. (Benziger Bros. edition, 1947), http://www.ccel.org/ccel/aquinas/summa.html, II-II, 182, 1.

31 ST II-II, 180, 2

32 ST II-II, 180, 4.

33 ST II-II, 184, 1. 
in this fellowship and colloquy with God, and to hope to attain to this fellowship.

Therefore charity is quite impossible without faith and hope. ${ }^{34}$

He makes an analogy between the trust required in human friendships and the faith required for friendship with God. Likewise, hope drives the continuing belief that the dialogue of friendship will continue and deepen. For Aquinas, charity expresses itself in friendship. Friendship includes benevolence, mutual love, and communication. Aquinas quotes Jesus' words in the Gospel of John, "It is written (Jn. I5:I5): 'I will not now call you servants...but My friends.' Now this was said to them by reason of nothing else than charity." 35

In summary, Aristotle considers friendships of equals to be mutually benevolent and to involve spending time together in shared contemplation and study. Virtue friendship includes the forming of the self through virtuous activities carried out in light of the friendship. The contemplative life is the highest form of life and requires friends, partly because people contemplate themselves through their friends. Augustine adds a Christian element to the question and explicitly states that all friends come from God and that friendship should be rooted in pursuit of God. God builds and transforms our friendships through grace. Aquinas follows Aristotle and Augustine and makes the move to identify our relationship with God most closely as friendship with God. Contemplation includes contemplation of God and of God's creation. Questions of finality and the selfsufficiency of the contemplative raised by Aristotle dissolve in Augustine and Aquinas, as they view Christian life and friendships as only partially fulfilled in this life, awaiting complete perfection in heaven. ${ }^{36}$

\section{How Friendship and Contemplation Activate the Transcendent Hope and Power of the Liberal Arts}

This section begins with a general discussion of the relationship between friendship and contemplation as they can be embodied in our campus contexts. Next, the paper moves beyond our three main conversation partners to explore how certain characteristics of friendship and contemplation also support and empower deep, sustained learning. Overall, the section will explore how the discipline and practices of friendship and contemplation can offer concrete and desirable ways to grow in love and understanding. The value of these practices lies in their ability to promote the integral development of the human person-students-as they live into their primary vocation of study in our

34 STI-II, 65, 5.

35 ST II-II, 23, 1.

36 The primacy of contemplation over friendship in service to human flourishing has long been a sticking point in the interpretation of Aristotle's ethics. From a Christian perspective, this conflict does not arise, as human fullness rests in a fundamentally communal and relational return to God. Contemplation from this perspective is not "self-sufficient" nor a primarily solitary experience. For a philosophical exploration of "contemplative friendship," see Daniel P. Maher, "Contemplative Friendship in Nicomachean Ethics," The Review of Metaphysics 65 (June 2012): 765-794. 
Catholic colleges and universities. ${ }^{37}$

Contemplation includes study and so is fundamental to the vocation of the student and of the teacher. Virtuous friendships or contemplative friendships amongst students as mentored by teachers have the ability to help students grow toward integral human development and an experience of transcendence. Friendships address the whole of what it means to be human and grow in knowledge and love through our mind, heart, soul, and body. In addition, faculty members and staff have need of contemplative friendships that reflect characteristics of equality, mutuality, communication, benevolence, and a seeking of truth. The stereotype that contemplation occurs only in church during adoration belies the understanding proposed here. Contemplation occurs, yes, in the classrooms and the library and the church, but also in the dorm rooms, in the hallways, on the sidewalks, in the common areas, and in the dining hall.

Contemplative friendships, since they support shared pleasure, mutual goals, and the other person's well-being, can serve to deepen human personhood in many ways. These relationships could lead to deeper and more intense study and questioning. More complex forms of knowledge and understanding arise. In addition, contemplative friends would grow in their self-knowledge, including learning about how they learn and what content they most desire to learn. These relationships offer support during times of personal challenge and difficulty. They also offer encouragement during the shared grind of hard work and daily labors.

Beyond a focus on study and work, the students can help each other grow in relationship with God. Likewise, contemplative friendships can help with the discernment of the work of God's spirit in the lives of believers. Contemplation of God consists of a developing friendship with God, through prayer, study, and reflection on one's experiences, driven by a desire to know and love God and God's creation more deeply. Friendship with others consists of contemplation of and with our friends. As Aristotle held, our friends are another self. What do we see in them that makes them other selves? What do they see in us? Friends form each other. Contemplatives think, see and reflect upon God and God's creation. Gazing with care into the eyes of another person bonds the two people in mutually receptive love. Infants are formed by the physical and visual connection with their parents. Love continues to form people in different embodied ways throughout life.

The paper turns now to explore some characteristics of friendship and contemplation that support the flourishing of the power and hope of the liberal arts that have not been addressed by our three interlocutors. First, our college and university campuses can provide many different perspectives from which to engage in reflection on the practices of contemplation and friendship. For example, narratives of fiction, history, and poetry address friendship and contemplation. Music and the visual arts portray them for

37 While this paper does not address the implications of friendship and contemplation specifically for Christian religious education, see David Shields, "Friendship: Context and Content of Christian Religious Education," Religious Education 91, No. 1 (Winter 1996): 104-121, for a discussion of the implications of friendship for religious education in ecclesial settings. 
their topics as well. Studies in the sciences look intimately at the book of nature, God's creation, to better understand God's many gifts. All areas in the liberal arts engage in communal study and reflection as friends seek the good of knowledge, understanding, and growth in love.

Next, contemplation as study, observation, or prayer takes discipline. Contemplation as prayer, conversation with God, and awareness of the world aims eventually at the grace of union with God. Simone Weil, in "Reflections on the Right Use of School Studies with a View to the Love of God," writes,

The key to a Christian conception of studies is the realization that prayer consists of attention. It is the orientation of all the attention of which the soul is capable towards God. The quality of the attention counts for much in the quality of the prayer. Warmth of heart cannot make up for it. It is the highest part of the attention only which makes contact with God, when prayer is intense and pure enough for such a contact to be established; but the whole attention is turned towards God. ${ }^{3} 8$

Weil relativizes the importance of study for the development of discipline to the sole purpose of developing greater attention in prayer.

Of course school exercises only develop a lower kind of attention. Nevertheless they are extremely effective in increasing the power of attention which will be available at the time of prayer, on condition that they are carried out with a view to this purpose and this purpose alone. ${ }^{39}$

Leaving behind Weil's insistence that the purpose of discipline learned in school studies have value only for prayer, or development for friendship with God, this paper argues that this same discipline and focus can apply to personal friendships and growth in love and knowledge. However, the discipline learned through the practices of study and friendship itself empowers and provides hope to the continued expansion of the liberal arts.

Discipline alone, however, cannot impel students to continually go beyond the boundaries of their learning. A basic curiosity and a desire to know must fuel their actions. Much has been said in recent years regarding passion and the pursuit of vocation. Passion for study of a certain body of knowledge or perhaps a certain career or way of serving the world has been the general emphasis of this work. These passions alone cannot fuel the transcendent hope and power of the liberal arts. Besides a basic curiosity and desire to know, students and faculty must root their desires in a passion for relationships that grounds themselves in a deep sense of benevolence toward others. While virtue friendships occur between equals, contemplative friendships can occur between students and faculty in a way very loosely analogous to the way in which a contemplative friendship occurs between a person and God. Contemplative friendships

38 Simone Weil, "Reflections on the Right Use of School Studies with a View to the Love of God," Waiting on God (London: Routledge and K. Paul, 1952), 105.

39 Weil, "Reflections," 105. 
do not leave the consideration of virtue behind, but frame the relationship of concern and desire to know within the horizon of God.

The passion reflected in our study and our relationships will influence our relationship with God. Contemplation of God is not only thinking about God but also going out of one's self toward God. Contemplation requires turning off the interior dialogue and listening deeply. The listening may be the receptive listening to God or to a friend, another self. Can we, as college faculty, staff, and administrators, practice receiving the other, simply and fully (perfectly) just as they are, now? Can we offer ourselves to God and our friends authentically and completely as we are, now?

\section{Besides a basic curiosity and desire to know, students and faculty must root their desires in a passion for relationships that grounds themselves in a deep sense of benevolence toward others.}

This movement entails ecstasis, the basic movement of transcendence, the going out of one's self toward God and others..$^{\circ}$ Catherine LaCugna follows Orthodox theologian John Zizioulas in her treatment of divine and human personhood. "God exists as the mystery of persons in communion; God exists hypostatically in freedom and ecstasis."4I This divine reality reveals something about human personhood as well.

We are accustomed in the West to think of freedom as the result of perfect selfpossession, the greater the degree of autonomy and self-determination and the prerogative of unlimited choices. Freedom, in other words, is located in the consciousness of a spiritual subject who acts, disposes, determines. For Zizioulas, freedom belongs to the arena of ecstasis and self-transcendence. Ultimately freedom, defined ontologically rather than morally, means conformity to the image of God in us. $4^{2}$

"Conformity to the image of God in us" entails seeing (contemplating) as God sees.

Seeing as God sees, from a Christian viewpoint, means also making Jesus' way of seeing our way of seeing. The paper began with a citation of the Great Commandment in the Gospel of Mark. A final question regarding friendship and contemplation remains: Who am I to befriend? In the version of the Great Commandment in the Gospel of Luke, Jesus addresses this very question.

40 Catherine Mowry LaCugna, God for Us: The Trinity and Christian Life (San Fransisco, CA: Harper Collins, 1991), 260-266.

41 LaCugna, God for Us, 260.

42 LaCugna, God for Us, 261. 
After Jesus responds to the lawyer by naming the Great Commandment, the story continues.

But because he wished to justify himself, he said to Jesus, "And who is my neighbor?" Jesus replied, "A man fell victim to robbers as he went down from Jerusalem to Jericho. They stripped and beat him and went off leaving him halfdead. A priest happened to be going down that road, but when he saw him, he passed by on the opposite side. Likewise a Levite came to the place, and when he saw him, he passed by on the opposite side. But a Samaritan traveler who came upon him was moved with compassion at the sight. He approached the victim, poured oil and wine over his wounds and bandaged them. Then he lifted him up on his own animal, took him to an inn and cared for him. The next day he took out two silver coins and gave them to the innkeeper with the instruction, 'Take care of him. If you spend more than what I have given you, I shall repay you on my way back.' Which of these three, in your opinion, was neighbor to the robbers' victim?” He answered, “The one who treated him with mercy.” Jesus said to him, "Go and do likewise." (Lk Io: 29-37 NAB)

The account begs the question, Why did the priest and the Levite see without seeing? Why did they cross the street to the other side to avoid responding to the man's suffering? How could the Samaritan love so much? When you love God with all of your being, when you see yourself, or your friend, or your God in your neighbor, you are more likely to love more deeply and more actively. The Samaritan came close to the victimized man. The Samaritan recognized his humanity and his needs. The Samaritan responded with great mercy and love. Not only did he offer initial love and care, but also a promise to return. The relationship had just begun.

\section{If friendship and contemplation can provide increasing power and hope to deep and sustained education, the question now expands: Can it do this for all college constituencies?}

How we actually see, who we see, and what we see is situated within and bound by the horizon within which we live. This horizon impacts both whom we befriend and how we see God. The tendency may literally be to not even physically or spiritually see the other, whether the other is distinct by way of need, gender, culture, or political or religious perspective.

\section{Questions for Further Reflection}

This closing section will raise a series of questions to be considered regarding the proposal of this paper whose answers go beyond the purpose of this paper. These questions 
offer directions for further reflection with regard to concerns of justice in friendship and contemplation on our college and university campuses. Going back to the original question, if friendship and contemplation can provide increasing power and hope to deep and sustained education, the question now expands: Can it do this for all college constituencies? In turn, the section will address issues of gender, cultural differences, economic and political location, and persons from diverse faith or of no faith backgrounds.

Generally, the current student population averages around $58 \%$ female and $42 \%$ male at private colleges. ${ }^{43}$ According to the National Center for Education Statistics' $201 \mathrm{I}$ Digest of Education Statistics, during the 20I0-II academic year, 62.9\% of students enrolled in Catholic universities and colleges were female; 37.I\% were male. ${ }^{44}$ Programs related to religion tend to have a female-male ratio of 3 to I or even 4 to I. The bulk of the theoretical work written on friendship and contemplation has been written mostly from male perspectives, and largely from celibate male perspectives. In fact, the types of friendships presumed in these discussions are largely presumed to be friendships among males. For example, while Augustine relates a beautiful story of communal contemplation with his mother, Monica, he would not have considered her a friend. ${ }^{45}$

John Stuart Mill wrote On the Subjection of Women to argue for women's political rights (the vote, property ownership, equal protections) based on his friendship with his wife as an equal. His perspective was that the order and relationships in the home and the order and relationships in society should reflect each other. ${ }^{4}$ However, Mill still intended a traditional division of labor between the spouses. He envisioned that the male would be the provider and that the female would maintain the home. He encouraged the education of women so as to ensure equality between the husband and wife. Moving forward, more reflection on the value of friendships of equals between men, between women and across the gender divide would be necessary.

Friendship can also express itself in various cultural forms. 47 Depending on the

43 Data from the National Center for Education Statistics' 2011 Digest of Education Statistics, at http:// higheredlive.com/missing-men/ Accessed 16 October 2013.

$44 \mathrm{http} / / /$ www.accunet.org/i4a/pages/index.cfm?pageid=3797\#Enrolled as accessed 16 October 2013.

45 Augustine, Confessions (New York: Penguin Books, 1983), 197-198.

46 See the treatment of this topic by Mary Lyndon Shanley, "Marital Slavery and Friendship: John Stuart Mill's The Subjection of Women" in Friendship: A Philosophical Reader (London: Cornell University Press, 1993), 267-284. John Stuart Mill and Harriet Taylor Mill, "The Subjection of Women" in Essays on Sex Equality (Chicago, IL: University of Chicago Press, 1970), 123-242.

47 For a treatment of culture and theology see Kathryn Tanner, Theories of Culture: A New Agenda for Theology (Minneapolis, MN: Augsburg, 1997). "Differences are not marked by boundaries separating self-contained cultures. On a post-modern understanding, cultural elements may cross such boundaries without jeopardizing the distinctiveness of different cultures. What establishes the distinctive identities of cultures in that case is the way in which such common elements are used, how they are handled and transformed. The distinctiveness of cultural identity is therefore not a product of isolation; it is not a matter of a culture's being simply self-generated, pure and unmixed; it is not a matter of "us" vs. "them." Cultural identity becomes, instead, a hybrid, relational affair, something that lives between as much as within cultures." Tanner, 57-58. 
cultural backgrounds of students, faculty, and staff, given their diversity or the lack thereof, colleges and universities may have more or less ease in exploring these themes with their students. What cultures comprise a given school? How do students from various cultural experiences relate to each other? How do friendships develop and express themselves in different cultures? Notions of time, space, physical expression of affection, familial relations, and language all will vary and impact friendships.

\section{Questions of the economic realities of our students and their families loom large.}

In addition, notions of contemplation as prayer and/or study may vary culturally. Is interior prayer considered prayerful and reflective or is it considered selfish and individualistic? Does a culture find silence to be an experience that mediates the presence of God or an experience that indicates the absence of the Spirit? How much do cultures value study, either in the sense of a deeper, more complex understanding or in a sense of the pursuit of the truth? Do cultures understand truth as an almost mathematical proof or do they find truth expressed in different ways? Contemplation has everything to do with how God loves people, how people experience this, and how people express love to God in return.

Beyond the importance of understanding cultural differences in light of friendship and contemplation, the question of the economic status of college students perhaps places an even greater challenge to our proposal. The friendship proposed here presumes friendship among equals. While literal economic equality may not be necessary, addressing the question of the economic status of Catholic college and university students and their friendships cannot be ignored. The reality of the value and cost of higher education has become a primary question for high-level administrators. Questions of the economic realities of our students and their families loom large. As the resource gap in our country continues to grow along with the gap between the superrich and the middle class, even families with two working parents can have difficulty providing funds for their children to go to college. Children live at home longer and leave college with higher debt levels.

So what do economic differences have to do with friendship and contemplation? Friendships involve spending time (and money) together. Initial attraction to other persons can be based on external perceptions, how they dress, wear their hair, or what car they drive or do not drive. Although we do not want to believe that our friendships would be based on economic similarities, only persons of certain economic means will even apply to college, let alone get accepted and attend. Contemplation, whether in the sense of interior prayer or study, can be critiqued as a leisure activity of the self-sufficient man available only to the fortunate few. 
The political divide has grown and continues to grow in our country. How often do we befriend persons with different political views? How often do we really engage these topics with persons whom we know differ from us in perspective? Could we really commit to a friendship relationship with someone of a different political perspective? We may pray with them at Eucharist, we may receive together the one body of Christ, but to actually have a meal together? How do we mentor our young to have these more difficult, potentially conflict-filled conversations in pursuit of truth in a way that reflects an honest desire to grow in love and mutual understanding?

Finally, the approach of Catholic colleges and universities to friendship and contemplation needs to consider not only their Catholic and Christian students but students of other faiths and of no faith. Communal learning, friendships, and a shared love of knowledge and truth among persons of different religions can go a long way toward growing daily in love for God, self, and others. Consider the document, "A Common Word Between Us and You" as an expression of communal contemplation and reflection that grew out of friendships and helped initiate new friendships between Christian and Muslim scholars. ${ }^{4}{ }^{8}$ Their work began out of the resonances between Islam and Christianity, grounded in love of the one God and love of neighbor. The document recognizes the demographic importance of peace between Christians and Muslims and after decrying any forms of violence between members of the two religions concludes with the call, "So let our differences not cause hatred and strife between us. Let us vie with each other only in righteousness and good works. Let us respect each other, be fair, just and kind to another and live in sincere peace, harmony and mutual goodwill."49

\section{Conclusion}

Will this proposal exploring how friendship and contemplation can empower the transcendent hope of the liberal arts in the context of Catholic higher education resonate with students and faculty? The answer remains to be seen. The experience of college faculty and administrators working on the Programs for the Theological Exploration of Vocation, funded by the Lilly Endowment, Inc., over the course of many years has indicated that students care deeply about their friendships, their learning, and their relationship with God..$^{\circ}$ Courses and programming on prayer, vocation, discernment, service, and friendship have abounded for years at the participating schools. Students want to love and be loved, to serve, to be faithful friends, and they want to know. They begin to learn the rigors of study and to develop more complex patterns of thinking. Regarding contemplation of God, many students have not even been introduced to the most basic

48 http://www.acommonword.com/the-acw-document/.

$49 \mathrm{http} / / /$ www.acommonword.com/the-acw-document/ In addition, for an exploration of Christian and non-Christian sources that influence Thomas Merton's understanding of contemplation, see Glenn Crider, "Thomas Merton's Contemplation: Rarefied Emblem of Being Human and Living in Mystery," Crosscurrents 58 (Dec 2008), 592-607.

50 See http://www.ptev.org/. 
prayer practices. Even students of no faith place high value on their relationships and their purpose in life.

Reflections on the classical marks of friendship, such as mutuality, equality, love, time spent together, and shared reflection or silence, could serve as a counterbalance to the context and culture of many Catholic universities. In our "community of communities," we have groups of students who only study, who have a solitary focus on their academic life, whether this occurs in a group or alone. We have groups of students interested in social justice activities that may not be interested in silent prayer and we have students who want to sit in front of the Eucharist in adoration but who cannot keep up their grades or develop friendships. We have students mostly interested in getting by academically and drinking and hooking-up whenever possible. We have students who focus on activities such as the arts, sports, and political engagement. Wherever these students find themselves during their college careers, they will be thinking, theorizing, seeing, observing, practicing, communicating, and striving for whatever they think to be the best for them.

This paper proposes one way to fertilize the soil of the context of Catholic higher education to enable the transcendent power and hope of the liberal arts to continue to grow. By conscious reflection on and the practice of contemplation and friendship, the constituents and institutions of Catholic higher education can continually go beyond themselves, in ecstatic movement, toward God and the world. 


\section{Bibliography}

Aquinas, Thomas. Summa Theologica. Fathers of the English Dominican Province, trans. Benziger Bros. edition, I947. http://www.ccel.org/ccel/aquinas/summa.html.

Aristotle. Richard McKeon, ed. The Basic Works of Aristotle. New York: Random House, I94I.

. Brad Inwood and Rafael Woolf, eds. The Eudemian Ethics. New York: Cambridge University Press, 2013.

Augustine. Confessions. New York: Penguin, I983.

Sermons. Edmund Hill, trans. Brooklyn, NY: New City Press, I990.

Badhwar, Neera Kapur. Friendship: A Philosophical Reader. Ithaca, N.Y.: Cornell University Press, I993.

Cooper, John M. “Aristotle on Friendship." In Essays on Aristotle's Ethics, edited by Amelie Oksenberg Rorty, 30I-340. Berkeley: University of California, I980.

Crider, Glenn. “Thomas Merton's Contemplation: Rarefied Emblem of Being Human and Living in Mystery." Crosscurrents 58 (2008): 592-607.

Erb, Heather McAdam. "From Rivulets to the Fountain's Source: Image and Love." In Aquinas' Christian Anthropology. Washington, DC: The Catholic University of America Press, 2009, 6I-9I.

Garrigou-Lagrange, Réginald and Timothea Doyle. Christian Perfection and Contemplation, According to St. Thomas Aquinas and St. John of the Cross. St. Louis: B. Herder, I937.

Halper, Edward C. "Aristotle and the Philosophy of Friendship." The Review of Metaphysics 57 (2003): 430-432.

Hanus, Jerome G. "Friendship in Aristotelian Ethics." Modern Schoolman: A Quarterly Journal of Philosophy 50 (I973): 351-365.

Hayden, R.M. "Aquinas and Natural Human Fulfillment: Inconsistencies.” American Catholic Philosophical Quarterly 65 (I991): 215-233.

Hitz, Zena. "Aristotle on Self-knowledge and Friendship.” Philosophers' Imprint II, no. I2 (2OII): I-28.

Kenny, Anthony. Aristotle on the Perfect Life. New York: Oxford University Press, I992.

Kilby, Karen. "Response to Matthew Levering." International Journal of Systematic Theology 9, no. I (2007): 55-57.

Kowalczyk, Stanislaw. “Topicality of St. Augustine's Concept of Wisdom.” Dialogue and Universalism, I6, Iss. 5-6 (2006): 83-89.

LaCugna, Catherine Mowry. God For Us: The Trinity and Christian Life. San Francisco, CA: Harper Collins, I99I.

Levering, Matthew. "Friendship and Trinitarian Theology: Response to Karen Kilby." International Journal of Systematic Theology 9, no. I (2007): 39-54.

Liu, Wei. “An All-inclusive Interpretation of Aristotle's Contemplative Life." Sophia. 50 (200I) 57-7I.

Maher, Daniel P. “Contemplative Friendship in Nicomachean Ethics.” Review of Meta- 
physics 65, no. 4 (2012): 765-794.

Meilaender, Gilbert. Friendship, a Study in Theological Ethics. Revisions, Book 2. Notre Dame, Ind.: University of Notre Dame Press, I982.

Mill, John Stuart and Harriet Taylor Mill. "The Subjection of Women.” In Essays on Sex Equality. Chicago, IL: University of Chicago Press, I970, I23-242.

Nussbaum, Martha C. The Fragility of Goodness: Luck and Ethics in Greek Tragedy and Philosophy. New York, NY: Cambridge University Press, I986.

Pope, Thomas and Hugh. On Prayer and the Contemplative Life. New York: Benziger, I9I4. Rorty, A.O. “The Place of Contemplation in Aristotle's Nicomachean Ethics.” Mind: A Quarterly Review of Philosophy 87 (I978): 343-358.

Russell, Kenneth C. "Loves in Conflict: Maritain on Marriage and Contemplation.” Église Et Théologie 7, no. 3 (1976): 333-340.

Schroeder, Donald N. "Aristotle on the Good of Virtue-Friendship." History of Political Thought I3, no. 2 (1992): 203-218.

Schwartz, Daniel. Aquinas on Friendship. Oxford: Clarendon Press, 2007.

Shields, David. Friendship: Context and Content of Christian Religious Education. Religious Education 9I, no. I (1996): I04-I2I.

Smith, Thomas W. Revaluing Ethics: Aristotle's Dialectical Pedagogy. Albany, NY: State University of New York Press, 200I.

Sommerfeldt, John R. Aelred of Rievaulx: Pursuing Perfect Happiness. New York: Newman Press, 2005 .

Tanner, Kathryn. Theories of Culture: A New Agenda for Theology. Minneapolis, MN: Augsburg, I997.

Tisseverasinghe, Therese. Aristotle on Happiness: The Communal Versus the Contemplative Life. Halifax, N.S.: Saint Mary's University, 2008.

Vernon, Mark. The Philosophy of Friendship. Basingstoke; New York: Palgrave Macmillan, 2005 .

Wadell, Paul J. Becoming Friends: Worship, Justice, and the Practice of Christian Friendship. Grand Rapids, Mich.: Brazos Press, 2002. Friends of God: Virtues and Gifts in Aquinas. American University Studies. Series VII, Theology and Religion. Vol. 76. New York: P. Lang, I99I. . Friendship and the Moral Life. Notre Dame, IN: University of Notre Dame Press, I989.

Weil, Simone. Waiting on God. London: Routledge and K. Paul, I952. 